\title{
Use of non-timber forest products from invasive alien Prosopis species (mesquite) and native trees in South Africa: implications for management
}

\author{
Ross T Shackleton ${ }^{1 *}$, David C Le Maitre ${ }^{1,2}$, Brian W van Wilgen ${ }^{1}$ and David M Richardson ${ }^{1}$
}

\begin{abstract}
Background: Prosopis species have been introduced to many areas outside their native range to provide benefits to local communities. Several Prosopis species and their hybrids (hereafter "mesquite") have, however, become naturalised and invasive and now generate substantial costs. Management options are limited because of the complex conflicts of interest regarding benefits and costs. Management policies and strategies must take account of such conflicts, but further insights are needed on the dimensions of uses and impacts before such information can be usefully applied. Current policy in South Africa allows for the growth and use of mesquite in one province, but not in others where its control is mandatory. We report on a study to quantify the direct use and perceptions of non-timber forest products (NTFPs) from mesquite and native trees in South Africa.
\end{abstract}

Methods: Semi-structures household interviews were conducted with various stakeholder groups to identify what tree products are used, to ascertain amounts used as well as to gauge perceptions of natural resource use between different tree species and use over time.

Results: The direct household use value of native trees was higher than that of mesquite, and local stakeholders attached greater value to products from native trees than from mesquite. Therefore, native trees are and will still be preferentially harvested, and mesquite is unlikely to offer protection to native species by providing an alternative source of products. Mesquite pods do, however, provide valuable additional resources (fodder and medicinal products). The use of both native trees and mesquite is decreasing as the incomes of poorer households rise and as alternative energy sources become available. The benefits and reliance on mesquite are not as high as previously assumed and the impacts from mesquite invasions create large problems for local communities.

Conclusion: This study provides further evidence that the impacts of mesquite exceed the benefits, lending support for a policy to reduce negative impacts.

Keywords: Biological invasions; Conflicts of interests; Cost vs. benefit; Management; Policy; Tree invasions

\section{Background}

\section{General introduction}

Thousands of plant species have been introduced to new locations by humans, especially during the last three centuries, to serve many purposes (Richardson 2011). Many have naturalised and some have become invasive (Rejmánek and Richardson 2013). Invasive plants often supply benefits to societies in their new ranges, but costs

\footnotetext{
* Correspondence: rtshackleton@gmail.com

${ }^{1}$ Centre for Invasion Biology, Department of Botany and Zoology,

Stellenbosch University, Matieland 7602, South Africa

Full list of author information is available at the end of the article
}

associated with these invasions often increase as the plants spread (Shackleton et al. 2007a; Kull et al. 2011). This typically results in the emergence of complex conflicts of interest, with some stakeholders calling for eradication or control of the invaders, while others promote their continued use (Shaanker et al. 2010; Kannan et al. 2014; Shackleton et al. 2014; van Wilgen and Richardson 2014). Some invasive plant taxa (e.g., Acacia and Pinus species) are commercially important for forestry and agroforestry (Richardson 2011), while many others (e.g., Acacia mearnsii, Opuntia ficus-indica and Prosopis species) provide useful resources such as fuelwood, 
fodder and fruit, and are important for local livelihoods (Pasiecznik et al. 2001; de Neergaard et al. 2005; Shackleton et al. 2007a, 2011; Richardson et al. 2015). However, these same species also cause substantial costs to local livelihoods and the environment (Shackleton et al. 2014; van Wilgen and Richardson 2014).

Non-timber forest products (NTFPs) are all biological materials other than timber that are harvested from trees for use and sale at the household level (De Ber and McDermott 1989). These include native and introduced species (Cunningham 2001). NTFPs are utilised for subsistence and commercial gain all over the world (Shackleton and Shackleton 2004) and account for $20 \%$ of the incomes of rural poor communities on average and are used by more than $85 \%$ of households in urban areas of southern Africa (Shackleton et al. 2007b; Davenport et al. 2012). The use and trade of NTFPs has potential to be used for poverty alleviation and social upliftment in developing countries in a sustainable way (Shackleton and Shackleton 2004); this includes various initiatives to promote the utilisation of invasive alien species of Acacia and Prosopis (Choge and Chikamai 2004; Pasiecznik et al. 2006; Shackleton et al. 2007a). The introduction of invasive species can bring benefits by supplying more NTFPs or novel NTFPs, but can simultaneously be detrimental to natural resources, changing traditional patterns of resource use in a positive or negative way (Shackleton et al. 2007a). For example, in South Africa's Eastern Cape province, $90 \%$ of households used invasive alien Acacia species (wattles) as their primary heat source, and $19 \%$ of households relied on wattles for cash incomes (de Neergaard et al. 2005). The sale of fruit from invasive stands of Opuntia ficus-indica in the Eastern Cape amounted to $9 \%$ of the yearly income of collector's households (Shackleton et al. 2011). In Malawi, Prosopis (thereafter "mesquite") provided $44 \%$ of households with an income source (Chikuni et al. 2004), and in India mesquite provided up to $70 \%$ of fuelwood needs for households in arid regions (Pasiecznik et al. 2001; Walter 2011). NTFPs from mesquite such as medicine, fodder, flour alternatives and charcoal, are sold commercially on a large scale worldwide (Shackleton et al. 2014). However, mesquite also generates numerous costs in the same areas, which negatively affect local biodiversity, ecosystem services, economies and local livelihoods (Shackleton et al. 2014).

The services that these invasive alien species provide and the costs that they generate have resulted in conflicts regarding their use and management in many developing countries (Low 2012; van Wilgen and Richardson 2014). The introduction of new plants has been labelled as "dangerous aid" as many of these invasive non-native species harm the same communities that were targeted for assistance in the long term (Low
2012). The presumed benefits of these species limit management options and lead to contradictory policies in many developing countries, while costs associated with the invasions continue to rise. For example, in the Northern Cape province, South Africa, mesquite is listed as a "Category 3" invasive "species" which means that the genus may remain in the prescribed area/province, but further planting, propagation or trade is prohibited expect for the pods from mesquite which are exempted, and may be used on private land. In other South African provinces, mesquite is a "Category 1" invader which means that invasive populations must be controlled (although the regulations do allow for ongoing use of pods) (NEM:BA, 2004; Act No. 10 of 2004: Alien and Invasive Lists 2014) (Department of Environmental Affairs 2014). This means that any trading of products derived from mesquite is illegal in South Africa. Similarly, policy in Kenya states that mesquite should be managed though utilisation to reduce rates of spread and impacts while at the same time benefitting local communities. This policy is controversial as it limits control options; for example biological control is excluded (Shackleton et al. 2014). Such policies that seek to reduce impacts while seeking to benefit communities are widespread in developing countries. The situation is very different in developed countries, where social upliftment does not feature in strategies for dealing with invasive species. In Australia, for example, mesquite is listed as a weed of national significance and legislation does not allow for utilisation (Australian Weeds Committee 2012). Similarly, European regulations issued in 2015 do not make it easy to utilise products from any invasive species (European Union 2014). Utilisation of natural resources is crucial for local livelihoods and social upliftment in developing countries (Shackleton and Shackleton 2004). Sustainable strategies for dealing with "conflict of interest" invasive species must address the relative value of useful invasive species, like mesquite.

The systematic study of the use and perceptions of invasive species relative to native species has been limited (Kull et al. 2011). People use many invasive species simply because they are there, and not to use them would be to forego an opportunity. This is exacerbated if the species provides a resource that is not available from native species (Shackleton et al. 2007a). However, the use and perceptions of conflict invasive species such as Australian acacias differ considerably in different areas (Kull et al. 2011). People often use both native and alien species for the same purposes, and it would be useful to understand the drivers and levels of such usage to develop policies that will minimise harm and maximise benefit. Both native and alien species must be considered when formulating broad conservation aims in rangelands (Milton et al. 2003). On the one hand the alien species could relieve pressure on native species, thus benefiting 
conservation. On the other hand, however, on-going invasion by the alien species could be very detrimental to native species and to ecosystem services. Furthermore, if the alien species is perceived to be useful, then there would be resistance to the implementation of control from those who benefit from the resource. A better understanding of the level of use, value and dynamics of NTPF uses and perceptions of invasive species is clearly important for formulating effective responses and to guide policy formation and management. The use of NTFPs is usually assumed to be sustainable, allowing for biodiversity conservation and economic development to co-exist (Negi et al. 2011), and this has been proposed for invasive species (Choge and Chikamai 2004). Sustainable outcomes are, however, rare. The situation is inevitably dynamic, with the net benefits that accrue shortly after introduction being steadily eroded as the species invades, resulting in net harm (van Wilgen and Richardson 2014). One needs to consider that even beneficial invasive species can also lead to negative externalities whereas native species do not. Therefore, it is crucial to ensure that the use and perceptions on NTFPs from native and invasive species are incorporated in strategies dealing with invasive species to ensure that the needs of local communities are met while ensuring the conservation of biodiversity and ecosystem services. Mesquite invasions in South Africa provide a good case study for gaining further insights on these issues.

\section{Mesquite in South Africa}

Several Prosopis species were introduced to a few localities in South Africa in the late 1800s. In the mid-1900s mesquite was widely promoted and planted by the Department of Agriculture as a fodder, fuelwood and shade resource to aid farmers who were struggling with a twodecade long drought in the arid parts of the country (Zimmermann 1991; Poynton 2009). Prosopis has since become the second most widespread invasive plant genus in South Africa after Australian acacias (van Wilgen et al. 2012). There is growing evidence that mesquite invasions in South Africa are having profound negative impacts on biodiversity (Dean et al. 2002; Steenkamp and Chown 1996; Schachtschneider and February 2013; Shackleton et al. 2015a, 2015b), ecosystem services (Ndhlovu et al. 2011; Dzikiti et al. 2013) and local livelihoods and economies (Wise et al. 2012; Shackleton et al. 2015c). Wise et al. (2012) estimated that the costs will soon exceed the benefits. Control efforts carried out to date have done little to arrest the rapid spread of invasive populations (van Wilgen et al. 2012). Three seedfeeding biological control agents (Algarobius prosopis, A. bottimeri and Neltumius arizonensis) have been released in South Africa, but have had limited effect. A. bottimeri failed to establish, and the other two have not substantially slowed rates of mesquite spread (Zachariades et al. 2011). Although almost 0.5 billion Rand (US\$ 50 million) was spent on mechanical and chemical control measures between 1996 and 2008 (van Wilgen et al. 2012) by the state-run Working for Water programme, invasions continue to spread rapidly and the associated negative impacts continue to rise (Wise et al. 2012). Additionally, South Africa's policy for dealing with mesquite highlights the extent to which complexities still exist relating to the use and management of mesquite within South Africa with contradictory policy in different provinces. There is clearly an urgent need for a national mesquite management strategy as there are still conflicting ideas over the use and the benefit supply of the genus and the social and ecological costs it generates within South Africa. However, before more effective management policies can be developed, further insights would be required regarding the relative use, benefits and perceptions of this invasive tree in South Africa as well as to assess if other options are available if mesquite is better managed.

This study therefore compares (1) the use of NTFPs from native trees and mesquite by different stakeholders within the invasive range of mesquite in South Africa; and (2) perceptions surrounding mesquite and native tree NTFPs. It is hypothesised that; (1) mesquite is used more than native species due to introduction history and the fact that is it highly invasive and so widespread; (2) the introduction of mesquite has led to the prevision and use of novel resources in the area; and (3) mesquite will be perceived to be more useful than native species by local communities.

\section{Methods}

Study site

The study took place in 10 cities, towns and villages across South Africa's Northern Cape province (Fig. 1). This area covers the core of the invasive range of mesquite species in South Africa and represents a cross section of different environmental and socio-political conditions. Invasive stands of mesquite in South Africa comprise a complex mixture of several species and their hybrids (Mazibuko 2012), and we will simply refer to as "mesquite". The study included rural and urban areas and areas with private and communal land tenure. Sampled human settlements included large towns with over 50,000 people (Kimberly and Upington), smaller towns with between 10,000 and 20,000 inhabitants (Calvinia, Carnavon and Prieska), and towns and villages with fewer than 5000 people (Brandvlei, Loeriesfontein, Kenhardt, Mier and Madibeng).

The legacy of apartheid is still clearly reflected in the wealth, education, and distribution of different racial 


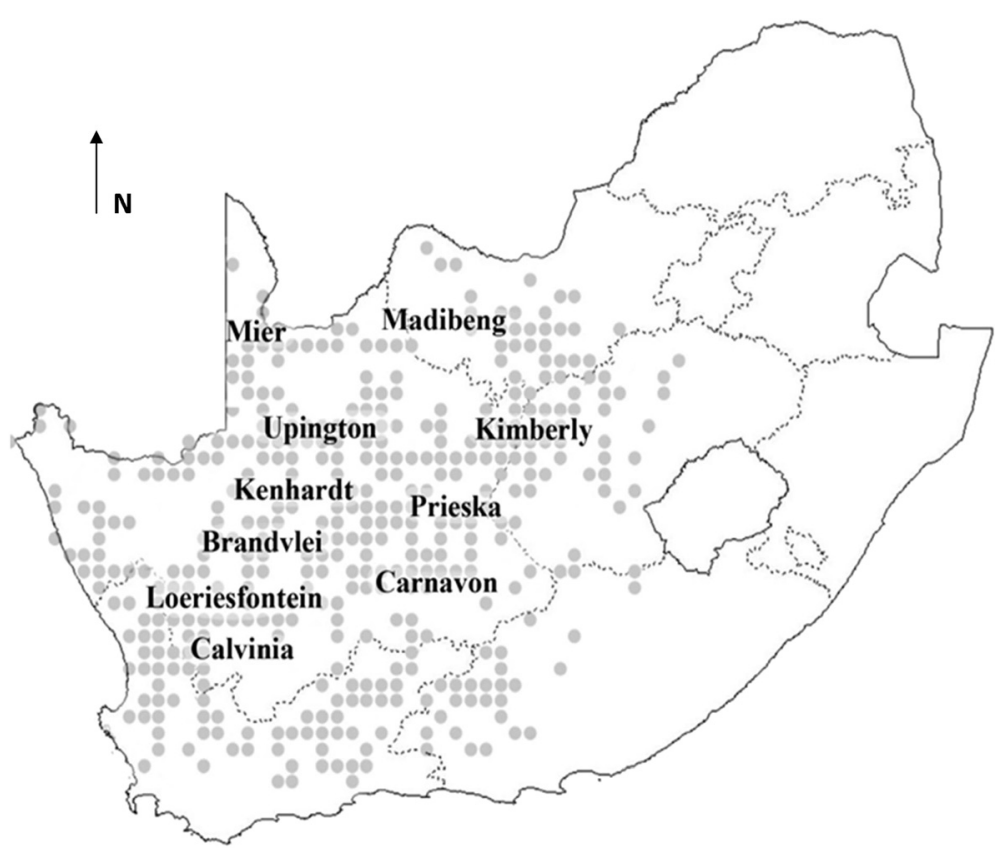

Fig. 1 Locations of the 10 towns in South Africa where interviews were conducted on the use of non-timber forest products from Prosopis species (mesquite) and native trees use. Dots represent the occurrence of invasive mesquite stands (Source of Map - Henderson, SAPIA database, ARC-Plant Protection Institute, Pretoria)

groups in the study area (Table 1) (Treiman 2007). Rural land is primarily owned by Whites and is run as game or livestock farms, although there are areas of communal land populated by Black and Coloured (mix-race) communities that were demarcated as "homelands" during the apartheid era. Stark contrasts are evident in urban areas, with moderately affluent suburbs (populated mainly by Whites) and informal settlements ("townships") populated by primarily Black and Coloured residents (Table 1). The economy of the region is based on mining, livestock, game and irrigated crop farming and tourism. The study area is semi-arid to arid, with mean annual rainfall averaging between 150 and $450 \mathrm{~mm}$ at different sites and falls within three biomes: the Succulent Karoo, Nama Karoo and Savanna (Mucina and Rutherford 2006).

\section{Interviews}

Semi-structured interviews were conducted with people from four main stakeholder groups - two in rural areas (land-owning farmers, and people living on communal lands) and two in urban areas (affluent suburbs and those living in poor informal settlements). These stakeholders provided a cross section of various groups who utilise natural resources and are influenced by mesquite. The interviews sought to uncover what NTFP products households used, the quantity of used, but also to

Table 1 Demographics (mean \pm standard deviation) of the sample populations of the different stakeholder groups interviewed across the study sites. ( $h \mathrm{~h}=$ household)

\begin{tabular}{|c|c|c|c|c|c|c|c|c|c|}
\hline $\begin{array}{l}\text { Stakeholder } \\
\text { category }\end{array}$ & $\begin{array}{l}\text { Mean age } \\
\text { (yrs) }\end{array}$ & $\begin{array}{l}\text { Gender } \\
\text { (\% male) }\end{array}$ & $\begin{array}{l}\text { Race group } \\
(\%)\end{array}$ & $\begin{array}{l}\text { Education } \\
\text { of hh head } \\
\text { (yrs) }\end{array}$ & $\begin{array}{l}\text { Mean no. } \\
\text { people } \\
\text { in hh }\end{array}$ & $\begin{array}{l}\text { Mean no. } \\
\text { wage earners } \\
\text { per hh }\end{array}$ & $\begin{array}{l}\text { Mean no. } \\
\text { state grants } \\
\text { per hh }\end{array}$ & $\begin{array}{l}\text { Mean no. } \\
\text { state pensions } \\
\text { per hh }\end{array}$ & $\begin{array}{l}\text { Modal income } \\
\text { bracket (Thousands } \\
\text { of Rand/month) }\end{array}$ \\
\hline \multirow[t]{2}{*}{ Farmers } & \multirow[t]{2}{*}{$53 \pm 134$} & \multirow[t]{2}{*}{81} & Coloured (12) & \multirow[t]{2}{*}{$13 \pm 3$} & \multirow[t]{2}{*}{$3 \pm 1$} & \multirow[t]{2}{*}{$2 \pm 0$} & \multirow[t]{2}{*}{$0 \pm 0$} & \multirow[t]{2}{*}{$0 \pm 0$} & \multirow[t]{2}{*}{$30-40$} \\
\hline & & & White (88) & & & & & & \\
\hline \multirow{2}{*}{$\begin{array}{l}\text { Communal } \\
\text { rural }\end{array}$} & \multirow[t]{2}{*}{$47 \pm 16$} & \multirow[t]{2}{*}{47} & Black (25) & \multirow[t]{2}{*}{$7 \pm 4$} & \multirow[t]{2}{*}{$5 \pm 3$} & \multirow[t]{2}{*}{$1 \pm 1$} & \multirow[t]{2}{*}{$2 \pm 1$} & \multirow[t]{2}{*}{$1 \pm 1$} & \multirow[t]{2}{*}{$0-5$} \\
\hline & & & Coloured (75) & & & & & & \\
\hline \multirow[t]{3}{*}{ Urban-Affluent } & \multirow[t]{3}{*}{$48 \pm 13$} & \multirow[t]{3}{*}{57} & Black (8) & \multirow[t]{3}{*}{$14 \pm 2$} & \multirow[t]{3}{*}{$3 \pm 1$} & \multirow[t]{3}{*}{$2 \pm 1$} & \multirow[t]{3}{*}{$0 \pm 0$} & \multirow[t]{3}{*}{$0 \pm 0$} & \multirow[t]{3}{*}{$>40$} \\
\hline & & & Coloured (4) & & & & & & \\
\hline & & & White (88) & & & & & & \\
\hline \multirow[t]{2}{*}{ Urban-Informal } & \multirow[t]{2}{*}{$48 \pm 33$} & \multirow[t]{2}{*}{38} & Black (28) & \multirow[t]{2}{*}{$8 \pm 4$} & \multirow[t]{2}{*}{$5 \pm 3$} & \multirow[t]{2}{*}{$1 \pm 1$} & \multirow[t]{2}{*}{$1 \pm 1$} & \multirow[t]{2}{*}{$1 \pm 1$} & \multirow[t]{2}{*}{$0-5$} \\
\hline & & & Coloured (72) & & & & & & \\
\hline
\end{tabular}


understand perceptions and trends about the use of NTFPs from mesquite and native trees. Households were selected at random by conducting interviews with all available households on randomly selected streets although some farmers were located through snowball sampling as many lived in towns rather than on their farms. The head of the household and/or those responsible for the collection of NTFPs were interviewed in their home language (Afrikaans, English, SeTswana, or isiXhosa). A translator was used for interviews in households where interviewees were not conversant in English.

A total of 639 household interviews were conducted across 10 sites between June and September 2014. These included 130 interviews with commercial farmers, 100 in rural communal land villages and 409 in urban areas (276 in informal settlements, 133 in affluent town suburbs). Farmers were interviewed at all 10 sites. Respondents from urban informal settlements and urban affluent areas were not interviewed at Mier and Madibeng as these areas only had rural villages on communal lands. Sample sizes varied across the stakeholder groups and were based on the demographics of different groups and the availability and ease of access for household interviews (Shackleton et al. 2015a). Farms in the area are widely separated making it costly and time-consuming to do many interviews. Unemployment is high in urban informal areas, so it was possible to conduct interviews throughout the day. In most households in urban affluent areas all the adults in the household worked so interviews could only be conducted for an hour a day in the early evenings and on weekends.

The interviews were semi-structured and comprised three main sections: (1) information regarding the demographics of the respondent household; (2) questions relating to use of mesquite and native trees; and (3) questions relating to perceptions of NTFPs supplied by mesquite and native species, and changes in patterns of use over time. This allowed us to gather information on the products and species utilised, amounts used, and local prices which allowed for the calculation of direct use values.

\section{Field measurements}

The key resources obtained from trees included fuelwood, pods used for various products, and fencing poles. For households that had NTFPs at their houses, daily quantities were measured using a spring scale. Many households bought resources from local traders, and indications of amounts bought per time frame were gathered. Local prices were obtained from traders. Quantities that people bought were measured at the local traders. Many households did not have NTFPs available for measurement, but respondents were able to estimate their usage in common units such as donkey carts or bakkie (small truck/ utility vehicle) loads per month or year. The contents of twelve bakkie loads and six donkey carts were weighed. This included eight bakkie loads of mesquite, two of Acacia erioloba and two of $A$. karroo wood and tree donkey carts of mesquite, two of A. erioloba and one of A. karroo wood. There were no significant differences in the mean weights of the different species. We standardised the data for wet bakkie loads (which still had fresh bark and were on average a third heavier) to that of dry bakkie loads by subtracting the mean difference between the two. The mean weight of a bakkie load of wood was $422 \pm 119 \mathrm{~kg}$. This is lower than the mean of $532 \mathrm{~kg}$ for three bakkie loads measured by Twine et al. (2003) - there was high variability based on the type of bakkie. The mean mass of a donkey cart load of wood was $156 \pm 66 \mathrm{~kg}$, marginally higher than the average of $132 \mathrm{~kg}$ per donkey cart found by Shackleton et al. (2006). Market values for fuel wood, honey and pods used to produce organic medicine were gathered from local traders at each of the study sites. Because there was no market for fodder and fencing poles, a substitute for mesquite pods for fodder -Lucerne pellets - was used ( 3.10 per $\mathrm{kg}$ ) and the value of native tree fencing poles was substituted for $3 \mathrm{~m}$ long Eucalyptus poles (R 40.00 per pole).

\section{Statistics}

T-tests were used to compare the total use and value (numerical data) of native tree species relative to mesquite. One-Way ANOVAs and Tukey post-hoc tests were used to compare use and value (numerical data) between different stakeholder groups. Chi-squared tests were used to compare the differences between usage by stakeholder groups and perceptions of mesquite and native species for variables with categorical data. All assumptions for each test were examined before the tests were run. Some groups of products have very small sample sizes precluding statistical analysis.

\section{Results}

\section{Uses of mesquite and native trees}

Fuelwood was the most common NTFP collected or bought for both mesquite and native species (Table 2). The proportion of fuelwood from native species and mesquite varied between stakeholder groups, and fuelwood from native species was used more amongst three stakeholder groups but marginally less by those in Urban Informal settlements who use mesquite slightly more often. Annual household use and the economic value of the use did not differ between mesquite and native trees at a household level. However, total use and value of native species was higher as more households use native species for fuel wood as compared to mesquite. The mean price of fuelwood from native species $(\mathrm{R} 1.8 / \mathrm{kg}$ ) was also slightly higher than that of mesquite fuelwood ( $\mathrm{R} 1.4 / \mathrm{kg}$ ). The overall household direct use value of 
Table 2 A comparison of fuel wood use of mesquite and native tree species for different stakeholders. Data are mean \pm standard deviation

\begin{tabular}{|c|c|c|c|c|c|c|c|c|c|}
\hline \multirow[b]{2}{*}{$\begin{array}{l}\text { Stake-holder } \\
\text { group }\end{array}$} & \multicolumn{3}{|c|}{ Mesquite fuelwood } & \multicolumn{3}{|c|}{ Native species fuelwood } & \multicolumn{3}{|c|}{ p-value (mesquite vs. native) } \\
\hline & $\begin{array}{l}\% \text { of hh } \\
\text { using }\end{array}$ & $\begin{array}{l}\text { Mean use (kg/ } \\
\mathrm{hh} / \mathrm{yr})\end{array}$ & $\begin{array}{l}\text { Mean value (R/ } \\
\text { hh/yr) }\end{array}$ & $\begin{array}{l}\% \text { of hh } \\
\text { using }\end{array}$ & $\begin{array}{l}\text { Mean use (kg/ } \\
\text { hh/yr) }\end{array}$ & $\begin{array}{l}\text { Mean value (R/ } \\
\mathrm{hh} / \mathrm{yr} \text { ) }\end{array}$ & $\begin{array}{l}\% \text { of hh } \\
\text { using }\end{array}$ & $\begin{array}{l}\text { Mean use } \\
(\mathrm{kg} / \mathrm{hh} / \mathrm{yr})\end{array}$ & $\begin{array}{l}\text { Mean value } \\
(\mathrm{R} / \mathrm{hh} / \mathrm{yr})\end{array}$ \\
\hline Farmers & 54 & $1648 \pm 1650^{\mathrm{a}}$ & $2060 \pm 2676^{a}$ & 85 & $1784 \pm 1892^{\mathrm{a}}$ & $2230 \pm 2523^{\mathrm{a}}$ & 0.03 & 0.630 & 0.85 \\
\hline $\begin{array}{l}\text { Communal } \\
\text { rural }\end{array}$ & 48 & $795 \pm 1021^{b}$ & $930 \pm 1229^{b}$ & 69 & $860 \pm 1110^{b}$ & $1125 \pm 1253^{b}$ & 0.04 & 0.17 & 0.48 \\
\hline Urban - affluent & 19 & $392 \pm 259^{b}$ & $586 \pm 343_{b}$ & 63 & $339 \pm 271^{c}$ & $641 \pm 553^{c}$ & 0.005 & 0.39 & 0.63 \\
\hline $\begin{array}{l}\text { Urban - } \\
\text { informal }\end{array}$ & 51 & $539 \pm 721^{b}$ & $979 \pm 1134_{b}$ & 48 & $528 \pm 626^{c}$ & $1155 \pm 1214^{b}$ & 0.869 & 0.09 & 0.42 \\
\hline
\end{tabular}

Superscript letters = significant differences between different stakeholder groups - Tukey post hoc test. hh = household

native tree fuelwood across all stakeholders was 1.2 times higher than that of mesquite. Acacia erioloba, A. karroo and $A$. mellifera made up the bulk of native species used followed by Parkinsonia africana and Searsia lancea. The use of mesquite wood also differed between stakeholder groups (Table 2). Farmers used more mesquite fuelwood than other groups. There was no difference in use and value of mesquite between other groups. Annual use of wood and annual value of fuel wood from native species also differed between different stakeholders (Table 2). Farmers used the most, followed by residents in Communal Rural villages and there were no differences between the urban stakeholder groups who used substantially less than the rural stakeholders.

Mesquite provided more direct-use services than native trees (Table 3). This included the collection of pods for fodder, beer and the manufacture of an organic blood sugar stabiliser marketed as "Manna". Pods were collected by farmers and milled to break the seed, so that they could feed them to livestock while eliminating the risk of spreading the seeds in dung. The collection of pods to produce Manna was restricted to one town (Prieska). Some farmers also collected honey produced from mesquite flowers. Respondents also mentioned that children opportunistically ate the pods from mesquite, but this was not included in the study as children could not be included in the study for ethical reasons. In rural areas numerous native tree species were used to make fencing poles. The value of NTFPs other than fuelwood was approximately 9.4 times higher for mesquite than for native trees. However, fuelwood use overshadowed this and, all together, the value of direct use NTFP products of native trees averaged 1.1 times more than that of mesquite (Tables 2 and 3). Interestingly, no households in Urban Affluent areas used other (besides for fuelwood) NTFPs from mesquite or native tree species (Table 3).

Modes of obtaining NTFP products differed between stakeholder groups for both mesquite and native tree species (Fig. 2). Most farmers and people living in rural communal areas collected products from mesquite and native species themselves, whereas in urban areas most people purchased these products. The proportion of people selling NTFPs was very similar across all stakeholder groups with $2 \%-3 \%$ of people selling mesquite and native tree products in Rural Communal areas and Urban-Affluent areas and up to $7 \%$ of respondents selling mesquite products from the Urban-Informal stakeholder group and $7 \%$ of farmers selling native tree species products. Farmers and people from Urban Affluent areas normally had larger-scale operations compared to the more informal trade within the Rural Communal

Table 3 Usage metrics (mean \pm standard deviation) for less commonly used non-timber forest products harvested from mesquite and native trees in South Africa. (hh = household)

\begin{tabular}{|c|c|c|c|c|c|c|c|c|c|}
\hline \multirow[b]{2}{*}{ Resource } & \multicolumn{3}{|l|}{ Farmers } & \multicolumn{3}{|c|}{ Communal rural } & \multicolumn{3}{|c|}{ Urban - informal } \\
\hline & $\begin{array}{l}\% \text { of hh } \\
\text { using }\end{array}$ & $\begin{array}{l}\text { Mean use (kg or I/ } \\
\text { hh/yr) }\end{array}$ & $\begin{array}{l}\text { Mean value (R/ } \\
\mathrm{hh} / \mathrm{yr})\end{array}$ & $\begin{array}{l}\% \text { of hh } \\
\text { using }\end{array}$ & $\begin{array}{l}\text { Mean use (kg or number } \\
\text { of poles/hh/yr) }\end{array}$ & $\begin{array}{l}\text { Mean value } \\
(\mathrm{R} / \mathrm{hh} / \mathrm{yr})\end{array}$ & $\begin{array}{l}\% \text { of hh } \\
\text { using }\end{array}$ & $\begin{array}{l}\text { Mean use (kg/ } \\
\text { hh/yr) }\end{array}$ & $\begin{array}{l}\text { Mean value } \\
\text { (R/hh/yr) }\end{array}$ \\
\hline \multicolumn{10}{|l|}{ Mesquite } \\
\hline Fodder & 3.8 & $1976 \pm 1669$ & $6125 \pm 5174$ & 2 & $200 \pm 0$ & $620 \pm 0$ & $>1$ & $960 \pm 0$ & 2976 \\
\hline Beer & - & - & - & - & - & - & $>1$ & $80 \pm 28$ & $120 \pm 82$ \\
\hline Manna & - & - & - & - & - & - & 2.2 & $1013 \pm 193$ & $1215 \pm 231$ \\
\hline Honey & $>1$ & 10 & 700 & - & - & - & - & - & - \\
\hline \multicolumn{10}{|c|}{ Native trees } \\
\hline $\begin{array}{l}\text { Fencing } \\
\text { poles }\end{array}$ & - & - & - & 4 & $29 \pm 23$ & $1170 \pm 912$ & - & - & - \\
\hline
\end{tabular}



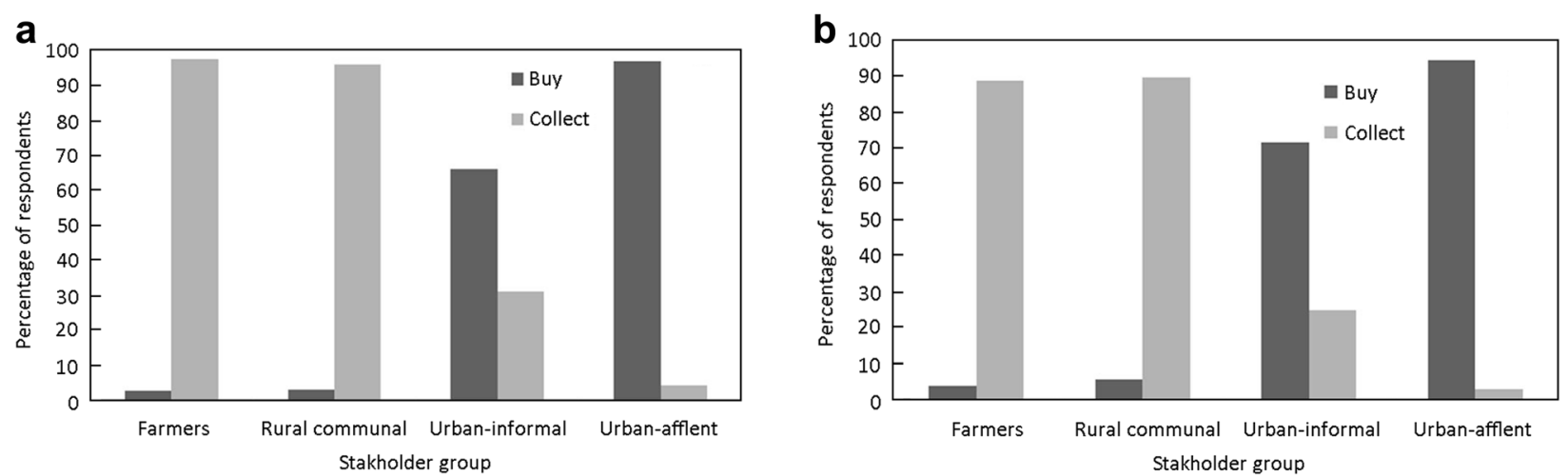

Fig. 2 Methods of securing non-timber forest products from (a) mesquite $-\left(x^{2}=255.8 ; p<0.0005\right)$ and (b) native species $\left(x^{2}=235.2 ; p<0.0005\right)$ for four stakeholder groups in South Africa

areas and Urban Informal areas and employed labourers to do the work, thus creating valuable jobs.

\section{Perceptions and trends over time}

In general, most households viewed the products provided by mesquite as inferior to native species - particularly in the case of fuelwood (Fig. 3). There were several reasons for this, including that mesquite wood does not generate as much heat or form coals as well as many native species; mesquite logs have smaller diameters than those from native species; mesquite has thick thorns that some people consider poisonous, making it relatively difficult to harvest and utilise; when the mesquite wood is slightly wet it produces an unpleasant smoke, and the most commonly mentioned reason was that the wood is rapidly powdered by a boring insect as it dries (which means that large quantities of wood cannot be stored for long periods) (Table 4). A small percentage of respondents preferred mesquite to native species, because it produces a highly nutritious fodder; invasive mesquite stands are often closer and more accessible to towns

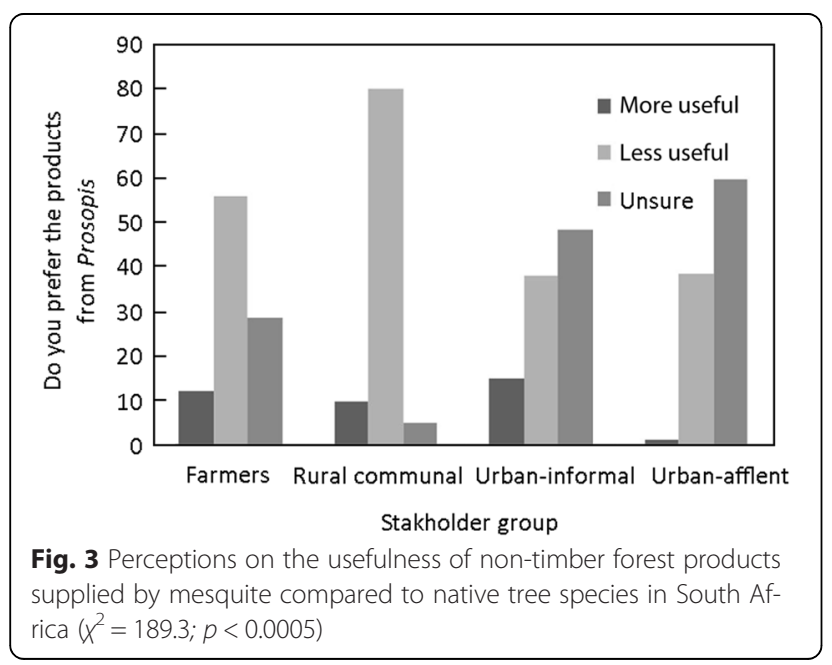

(making wood collection cheaper and faster); and some households make beer out of the pods (Table 4). Another reason for preferring to use mesquite was because the wood could easily be collected from debris left by government-sponsored clearing projects. Many people in the Urban Affluent stakeholder group were unsure whether mesquite products were better than native tree products and had no particular preference (Fig. 3).

In general, most stakeholders were either using the same amount of mesquite or native tree species, or have decreased their use of fuel wood over the last 10 years (Fig. 4). The primary reasons for reduced use - particularly in Urban-Informal settlements and in Rural Communal villages - is the recent electrification of these areas, and increased incomes through grants enabling many people to move to alternative energy sources such as electricity and gas. Only a small proportion of people in all stakeholder groups have increased their use of mesquite or native trees for NTFPs. Reasons for increased use include: bigger families driving a greater demand for wood, and the lower cost of fuel wood compared to electricity. Some people have increased their use of mesquite compared to native trees as the mesquite has spread rapidly making the wood are more accessible. Some farmers have also increased their use of mesquite as they are making more effort to control it and so use the wood of trees that have been cut down. Most people in Urban-Affluent areas used the wood primarily for barbeques, a strong tradition in the area, and are using about the same amount of wood as in the past.

\section{Discussion}

Many previous studies of NTFP use from invasive alien plants have focused only on the use value of a single species and provided no comparisons with usage of native species (Chikuni et al. 2004; de Neergaard et al. 2005; Shackleton et al. 2007c; Shackleton et al. 2011). Such a comparison is important to illustrate the potential value invasive species can provide but also gives insight into the other alternatives 
Table 4 Views of different stakeholders (\% of respondents) on the negative $\left(x^{2}=4.05 ; p=0.29\right)$ and positive $\left(x^{2}=11.5 ; p=0.0006\right)$ aspects of mesquite non-timber forest product provision as compared to those supplied by native trees

\begin{tabular}{|c|c|c|c|c|c|c|c|}
\hline \multirow[b]{2}{*}{ Stakeholder group } & \multicolumn{4}{|l|}{ Negative } & \multicolumn{3}{|l|}{ Positive } \\
\hline & Bad smoke & Poor quality wood & Thorns & Turns to dust & Fodder & Make beer & More accessible \\
\hline Farmer & 1.8 & 31.1 & 19.8 & 37.0 & 11.3 & - & 1.8 \\
\hline Rural Communal & 4.6 & 25.8 & 24.2 & 38.5 & 7.0 & - & 3.0 \\
\hline Urban - Affluent & - & 53 & 6.3 & 40.1 & - & - & 1.6 \\
\hline Urban - Informal & 7.3 & 25.7 & 28.6 & 28.8 & 10.7 & 1.1 & 3.7 \\
\hline
\end{tabular}

and the potential opportunity costs of their use. This study has shown that the direct use and value of resources provided by an introduced "wonder plant" which has now become a major invader - mesquite - is not as high as high as that of native trees in the arid parts of South Africa. This suggests that the benefits provided by mesquite are not as high as previously assumed, and with rising costs associated with spreading invasions, management interventions to reduce the extent and density of mesquite are becoming increasingly justifiable.

\section{Findings in relation to hypotheses}

(1) We hypothesised that mesquite would be used more than native species. Our findings indicate, however, that native species - particularly Acacia species - provide higher value for direct household use to local stakeholders than mesquite provides (Tables 2 and 3). The bulk of this use is for fuelwood which is the most commonly utilised NTFP in other parts of South Africa as well (Twine 2005; Davenport et al. 2012). This suggests that mesquite is less useful than previously assumed. It also means that the pressure on native tree populations remains high as they are still being utilised and are being displaced by invasive mesquite (Schachtschneider and February 2013; Shackleton et al. 2015b, 2015c).
(2) We hypothesised that the introduction of mesquite would lead to the provision and use of novel resources in the area, which it has, as mesquite provides a greater diversity of products than native trees in the study area. The most important novel resource is pods which are valued for fodder and to a smaller extent for the production of an organic medicine and brewing alcohol (in one town) (Table 3). This study did not quantify the value of consumption of pods by livestock in rangelands, although this is high (Wise et al. 2012). However, any assessment of the value of pods as fodder would have to factor in the loss of grazing where mesquite invades (Ndhlovu et al. 2011), as well as the role of livestock in spreading mesquite seeds in their dung (Shiferaw et al. 2004).

(3) We hypothesised that the natural resources provided by mesquite would be preferred to those of native trees. However, our findings indicate that the majority of stakeholders prefer native trees over mesquite and see products of native species as superior (Fig. 3). This is mainly because the wood quality of mesquite is perceived as poor for the reasons highlighted in Table 4, and fuel wood is the most widely used NTFP in the area. In Ethiopia when production of charcoal was legalised in an attempt to control mesquite through utilization, locals substituted mesquite with native Acacia tortilis and $A$. nilotica because these native species
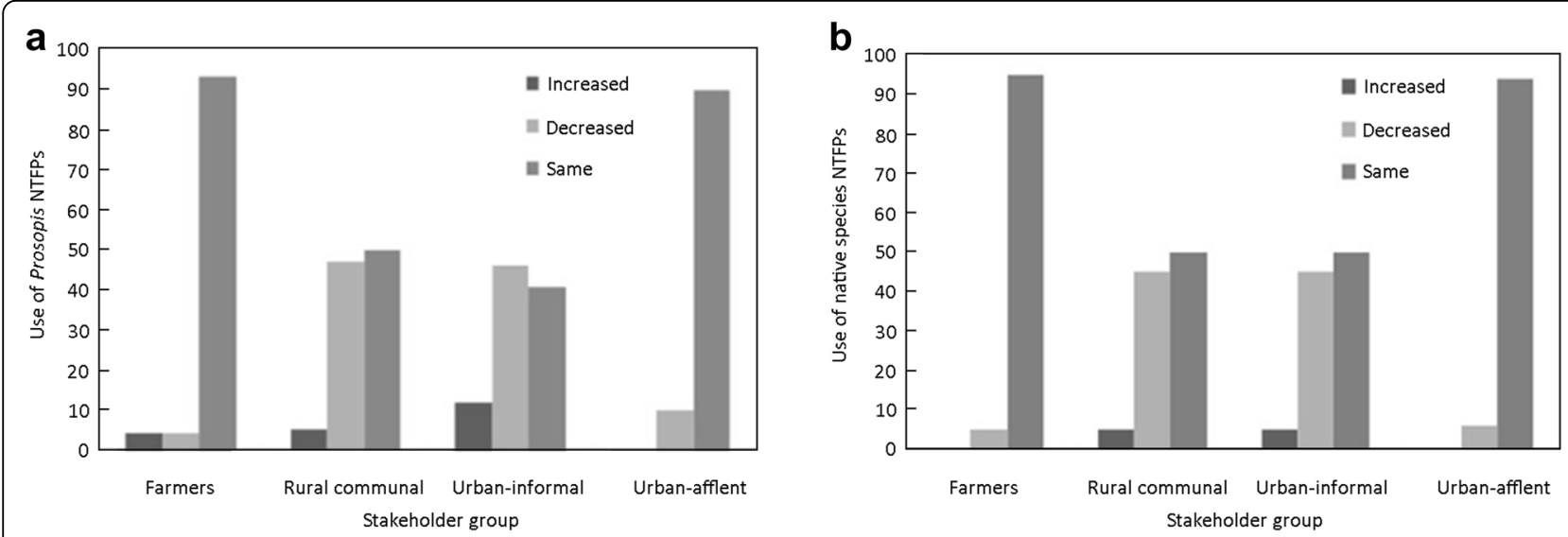

Fig. 4 A comparison of the use of (a) mesquite $\left(X^{2}=130.0 ; p<0.0005\right)$ and (b) native species $\left(x^{2}=111.5 ; p<0.0005\right)$ since the year 2000 in South Africa 
produced larger boles, had smaller spines and were easier to harvest, and because there were perceptions that the smoke from mesquite was poisonous (A. Witt: unpublished data). This provides another example illustrating that native species are favoured over mesquite, and highlights that planting alien species is unlikely to replace the use of native species, or to protect them. The supply of pods (a novel resource) from mesquite was the main reason why a small percentage of respondents preferred mesquite over native trees. Mesquite fuelwood was also favoured not because of its quality but because it could more easily be accessed. This has been noted elsewhere; for example, wood from $A$. mearnsii was perceived to be of lower quality than native species in the Eastern Cape of South Africa, but because it was more abundant close to villages it was used more (Shackleton et al. 2007a). Different perceptions relating to the use of natural resources of invasive species therefore often relate to their abundance, proximity, novelty, social contexts, factors surrounding introductions, cultural preferences and the opportunity costs of not using them (Shackleton et al. 2007a; Kull et al. 2011).

\section{Use patterns and perceptions}

Most previous studies have assessed patterns of use within defined socio-economic groups (Twine et al. 2003; Shackleton et al. 2007c; Paumgarten and Shackleton 2009; Davenport et al. 2012; Thondhlana et al. 2012), and not between groups. Our study revealed that use patterns, methods of obtaining the resources, and use over time varied between stakeholders within different social-economic and land tenure contexts (Tables 2 and 3; Figs. 2, 3 and 4). We found that those living closer to invasions (farmers and people in rural communal land villages) mainly collected the NTFPs themselves, whereas people in urban areas relied more on purchasing these resources. People living in more rural areas also used a higher value of NTFPs compared to those in urban areas. Interestingly, the traditionally poorer stakeholders are moving away from use of fuelwood (Fig. 4) as they adopt alternative energy sources such as electricity, gas and paraffin. The decreasing reliance on natural products has also been highlighted in other parts of South Africa, and has been linked to increased electrification and increased incomes especially through state grants and pensions (Shackleton et al. 2013). However, other sources suggest that the use of NTFPs, especially on a commercial scale, is increasing in some areas (Twine 2005). Those in wealthier stakeholder groups still use similar amounts of NTFPs as there is a strong culture of using wood for barbequing.

\section{Benefits vs. costs}

Wise et al. (2012) estimated that mesquite invasions were providing a net benefit to local communities in South Africa, but that a net loss will result shortly as mesquite trees continue to spread. Although mesquite is providing about half of the farmers in the Northern Cape with a mean direct-use value R 2000 per annum, the mean expenditure of farmers to control mesquite is over R 20000 per farm per annum (Shackleton et al. 2015a). Mesquite invasions have also led to numerous other social, ecological and economic costs such as negative impacts on water, grazing potential, biodiversity and infrastructure that have not been fully valued (Ndhlovu et al. 2011; Dzikiti et al. 2013; Shackleton et al. 2015a, 2015c). This suggests that mesquite invasions in South Africa generate more costs than benefits. Some argue that mesquite invasions play a positive role in that they reduce the use and pressure on native trees (Food and Agriculture Organisation FAO 2004). However, mesquite invasions are having large-scale negative impacts on native tree population stability, abundance, density and mortality in South Africa (Schachtschneider and February 2013; Shackleton et al. 2015b, 2015c) and natives are still being harvested in preference to mesquite. Native trees will therefore decline as mesquite stands become more widespread and dense, possibly more so than as a result of direct harvesting. In Kenya, mesquite is negatively impacting populations of native species that supply specialised NTFPs, e.g., a palm (Hyphaene compressa) used for weaving and thatching (Stave et al. 2007).

\section{Conclusion}

This study, focussing on invasive mesquite species, illustrates the benefit of understanding the conflicts of interest caused by invasive species within the developing world, and how understanding natural resource use is important for informing policy and management. We suggest that similar studies in other parts of the world would help to highlight the relative values of the resources provided by invasive species and to determine whether invasive alien species provide any unique resources that may be affected by management. Our study has shown that people preferentially use native species over mesquite and are decreasing their reliance's on natural resources from trees in general. It also highlights that alternative native species are available, if mesquite was substantially reduced through more effective management. Current policy in South Africa is attempting to simultaneously maximise benefits and minimise harm, but this approach is likely to lead to growing negative impacts and continued spread. It would be better to base policy direction on overall net benefit or loss. Wise et al. (2012) predicted that a situation of net losses would 
arise soon, and that the magnitude of the net loss would grow rapidly as mesquite continues to spread. It would therefore appear to be better to adapt policy and treat mesquite as an undesirable invasive species everywhere (category 1), and consider using more damaging biological control agents (not only seed-attacking insects).

\section{Competing interests}

The authors declare that they have no competing interests.

\section{Authors' contributions}

All authors conceived the study. RTS collected the data, performed statistical analysis. All authors helped to draft manuscript. All authors read and approved the final manuscript.

\section{Acknowledgements}

We thank all the participants who were interviewed and the translators for their hard work. This research was supported by the DST-NRF Centre of Excellence for Invasion Biology and Working for Water Programme through their collaborative research project on "Integrated management of invasive alien species in South Africa" and the National Research Foundation (grant 85417 to DMR).

\section{Author details}

${ }^{1}$ Centre for Invasion Biology, Department of Botany and Zoology, Stellenbosch University, Matieland 7602, South Africa. ${ }^{2}$ Centre for Invasion Biology, Natural Resources and the Environment, CSIR, P.O. Box 320, Stellenbosch 7599, South Africa.

\section{Received: 16 March 2015 Accepted: 4 May 2015}

Published online: 16 May 2015

\section{References}

Australian Weeds Committee (2012) Mesquite (Prosopis spp.) strategic plan 2012-17. Weeds of National Significance, Australian Governmental Department of Agriculture, Fisheries and Forestry, Canberra

Chikuni MF, Dudley CO, Sambo EY (2004) Prosopis glandulosa Torry (Leguminosae-Mimosoidae) at Swang'oma, Lake Chilwa plain: A blessing in disguise. Malawi J Sci Tech 7:10-16

Choge SK, Chikamai BN (2004) Experiences of Prosopis utilization and management from outside Kenya. In: Proceedings of the workshop on integrated management of Prosopis species in Kenya. KEFRI, Kenya - Nairobi

Cunningham AB (2001) Applied Ethnobotany. Earthscan, London

Davenport NA, Shackleton CM, Gambiza J (2012) The direct use value of municipal commonage goods and services to urban households in the Eastern Cape, South Africa. Land Use Policy 29:548-557

De Ber JJ, McDermott M (1989) The economic value of non-timber forest products in South East Asia. The Netherlands Committee for IUCN, Amsterdam

de Neergaard A, Saarnak C, Hill T, Khanyile M, Berzosa AM, Birch-Thomsen T (2005) Australian wattle species in the Drakensberg region of South Africa - An invasive alien or a natural resource. Agric Syst 85:216-233

Dean WRJ, Anderson MD, Milton SJ, Anderson TA (2002) Avian assemblages in native Acacia and alien Prosopis drainage line woodland in the Kalahari, South Africa. J Arid Environ 51:1-19

Department of Environmental Affairs (2014) National environmental management: Biodiversity act 2004 (Act no. 10 of 2004): Alien and invasive species lists, 2014. Department of Environmental Affairs, Pretoria

Dzikiti S, Schachtschneider K, Naiken V, Gush M, Moses G, Le Maitre DC (2013) Water relations and the effects of clearing invasive Prosopis trees on groundwater in an arid environment in the Northern Cape, South Africa. J Arid Environ 90:103-113

European Union (2014) Regulation (EU) No 1143/2014 of the European Parliament and the Council of 22 October 2014: On the prevention and management of the introduction and spread of invasive species. Official Journal of the European Union

Food and Agriculture Organisation (FAO) (2004) The introduction of Prosopis spp. in the drylands of the world. Pledge or plight for biodiversity. Food and Agriculture Organisation (FAO), Plant Production and Protection Division, Rome, Italy
Kannan R, Shackleton CM, Shaanker RU (2014) Invasive alien species as drivers of socio-ecological systems: local adaptions towards use of Lantana in Southern India. Environ Dev Sustain 16:649-669

Kull CA, Shackleton CM, Cunningham PJ, Ducatillon C, Dufour-Dror J, Esler KJ, Friday JB, Gouveia AC, Griffin AR, Marchante E, Midgley SJ, Pauchard A, Rangan H, Richardson DM, Rinaudo T, Tassin J, Urgenson LS, von Maltitz GP, Zenni RD, Zylstra MJ (2011) Adoption, use and perception of Australian acacias around the world. Divers Distrib 17:822-836

Low T (2012) In denial about dangerous aid. Biol Invasions 14:2235-2236

Mazibuko DM (2012) Phylogenetic relationship of Prosopis in South Africa: An assessment of the extent of hybridization, and the role of genome size and seed size in the invasion dynamics. MSc Dissertation, Stellenbosch University

Milton JJ, Dean WRJ, Richardson DM (2003) Economic incentives for restoring natural capital in southern African rangelands. Front Ecol Environ 1:247-254

Mucina L, Rutherford MC (2006) The vegetation of South Africa, Lesotho and Swaziland. Strelitzia, 19. South African National Biodiversity Institute, Pretoria

Ndhlovu T, Milton-Dean SJ, Esler KJ (2011) Impact of Prosopis (mesquite) invasion and clearing on the grazing capacity of semiarid Nama Karoo rangeland, South Africa. Afr J Range Forage Sci 28:129-137

Negi VS, Maikhuri RK, Rawat LS (2011) Non-timber forest products (NTFPs): a viable option for biodiversity conservation and livelihood enhancement in central Himalaya. Biodiver Conserv 20:545-559

Pasiecznik NM, Felker P, Harris PJC, Harsh LN, Cruz G, Tewari JC, Cadoret K, Maldonado LJ (2001) The Prosopis juliflora-Prosopis pallida complex: A monograph. HDRA, Coventry, UK

Pasiecznik NM, Choge SK, Muthike GM, Chesang S, Fehr C, Blackwell-Stone P, et al (2006) Putting knowledge on Prosopis into good use in Kenya. Pioneering advances in 2006. KEFRI and HDRA, Nairobi and Coventry

Paumgarten F, Shackleton CM (2009) Wealth differentiation in household use and trade in non-timber forest products in South Africa. Ecol Econ 68:2950-2959

Poynton RJ (2009) Tree planting in southern Africa, volume 3: Other genera. Department of Agriculture, Forestry and Fisheries, Pretoria, South Africa

Rejmánek M, Richardson DM (2013) Trees and shrubs as invasive alien species - 2013 update of the global database. Divers Distrib 19:1093-1094

Richardson DM (2011) Forestry and agroforestry. In: Simberloff D, Rejmánek M (eds) Encyclopedia of biological invasions. University of California Press, Berkeley, pp 241-248

Richardson DM, Le Roux JJ, Wilson JRU (2015) Australian acacias as invasive species: Lessons to be learnt from regions with long planting histories. Southern Forests 77:31-39

Schachtschneider K, February EC (2013) Impact of Prosopis invasion on a keystone tree species in the Kalahari Desert. Plant Ecol 214:597-605

Shaanker RU, Joseph G, Aravind NA, Kannan R, Ganeshaiah KN (2010) Invasive plants in tropical human-dominated landscapes: need for an inclusive management strategy. In: Perrings C, Mooney H, Williamson M (eds) Biodiversity and globalisation: ecology, economics, management and policy. Oxford University Press, Oxford, pp 202-219

Shackleton C, Shackleton S (2004) The importance of non-timber forest products in rural livelihood security and as safety nets: a review of evidence from South Africa. S Afr J Sci 100:658-664

Shackleton CM, McConnachie M, Chauke MI, Mentz J, Sutherland F, Gambiza J, Jones R (2006) Urban fuelwood demand and markets in a small town in South Africa: Livelihood vulnerability and alien plant control. Int J Sust Dev World Ecol 13:481-409

Shackleton CM, McGarry D, Fourie S, Gambiza J, Shackleton SE, Fabricius C (2007a) Assessing the effects of invasive alien species on rural livelihoods: Case examples and a framework from South Africa. Hum Ecol 35:113-127

Shackleton CM, Shackleton SE, Buiten E, Bird N (2007b) The importance of dry woodlands and forests in rural livelihoods and poverty alleviation in South Africa. For Policy Econ 9:558-577

Shackleton CM, Gambiza J, Jones R (2007c) Household fuelwood use in small electrified towns of the Makana District, Eastern Cape, South Africa. J Energy S Afr 18:4-10

Shackleton SE, Kirby D, Gambiza J (2011) Invasive plants - friends or foes? contribution of prickly pear (Opuntia ficus-indica) to livelihoods in makana municipality, eastern cape, south africa. Dev S Afr 28:177-193

Shackleton RT, Shackleton CM, Shackleton SE, Gambisa J (2013) Deagrarianisation and forest revegetation in a biodiversity hotspot on the Wild Coast, South Africa. PLoS One 8, e76939. doi:10.1371/journal.pone.0076939.11111

Shackleton RT, Le Maitre DC, Pasiecznik NM, Richardson DM (2014) Prosopis: a global assessment of the biogeography, benefits, impacts and management of one of the world's worst woody invasive plant taxa. AoB Plants 6:plu027. doi:10.1093/aobpla/plu027 
Shackleton RT, Le Maitre DC, Richardson DM (2015a) Stakeholder perceptions and practices regarding Prosopis (mesquite) invasions and management in South Africa. Ambio. doi:10.1007/s13280-014-0597-5

Shackleton RT, Le Maitre DC, Richardson DM (2015b) Prosopis invasions in South Africa: Population structures and impacts on native tree population stability. J Arid Environ 114:70-78

Shackleton RT, Le Maitre DC, van Wilgen BW, Richardson DM (2015c) The impact of invasive alien Prosopis species (mesquite) on native plants in different environments of South Africa. S Afr J Bot 97:25-31

Shiferaw H, Teketay D, Nemomissa S, Assefa F (2004) Some biological charecteristics that foster the invasion of Prosopis juliflora (Sw.) DC at Middle Awash Rift Valley Area, north-eastern Ethiopia. J Arid Environ 58:135-154

Stave J, Oba G, Nordal I, Stenseth NC (2007) Traditional ecological knowledge of a riverine forest in Turkana, Kenya: implications for research and management. Biodivers Conserv 16:1471-1489

Steenkamp HE, Chown SL (1996) Influence of dense stands of an exotic tree, Prosopis glandulosa Benson, on a Savanna dung beetle (Coleoptera: Scarabaeinae) assemblages in southern Africa. Biol Conserv 78:305-311

Thondhlana G, Vedeld P, Shackleton SE (2012) Natural resource use, income and dependence among San and Mier communities bordering the Kgalagadi Transfrontier Park, southern Kalahari, South Africa. Int J Sust Dev World Ecol 19:460-720

Treiman D (2007) The legacy of apartheid: Racial inequalities in the new South Africa. In: Heath FS, Cheung SY (eds) Unequal chances: Ethnic minorities in western labour markets. Oxford University Press, Oxford, pp 1-48

Twine W (2005) Socio-economic transitions influence vegetation change in the communal rangelands of South African lowveld. Afr J Range Forage Sci 22:93-99

Twine W, Moshe D, Netshiluvhl T, Siphuga V (2003) Consumption and direct use values of savanna bio-resources used by rural households in Mametja, a semi-arid area of Limpopo province, South Africa. S Afr J Sci 99:467-473

van Wilgen BW, Richardson DM (2014) Challenges and trade-offs in the management of invasive alien trees. Biol Invasions 16:721-734

van Wilgen BW, Forsyth GG, Le Maitre DC, Wannenburgh A, Kotze DF, van den Berg $E$, Henderson $L$ (2012) An assessment of the effectiveness of a large, national-scale invasive alien plant control strategy in South Africa. Biol Conserv 148:28-38

Walter K (2011) Prosopis, an alien among the sacred trees of South India. University of Helsinki Tropical Forestry Reports 38. 202

Wise RM, van Wilgen BW, Le Maitre DC (2012) Costs, benefits and management options for an invasive alien tree species: The case of mesquite in the Northern Cape, South Africa. J Arid Environ 84:80-90

Zachariades C, Hofmann JH, Roberts A (2011) Biological control of mesquite (Prosopis species) (Fabaceae) in South Africa. Afr Entomol 19:402-415

Zimmermann HG (1991) Biological control of Prosopis spp. (Fabaceae), in South Africa. Agr Ecosys Environ 37:175-186

\section{Submit your manuscript to a SpringerOpen ${ }^{\circ}$ journal and benefit from:}

- Convenient online submission

- Rigorous peer review

- Immediate publication on acceptance

- Open access: articles freely available online

- High visibility within the field

- Retaining the copyright to your article

Submit your next manuscript at $>$ springeropen.com 